\title{
Intercultural Communication: Strategy to Improve School Competitiveness Based on Public Demand
}

\author{
Zamroni $^{1 凶}$, Hasan Baharun ${ }^{2}$, Fathor Rozi ${ }^{3}$, Wahidatus Sholeha4 ${ }^{4}$, Yuliana Anggraini ${ }^{4}$ \\ Manajemen Pendidikan Islam, Universitas Islam Negeri Sultan Aji Muhammad Idris, \\ Samarinda, Indonesia(1) \\ Manajemen Pendidikan Islam, Universitas Nurul Jadid, Paiton, Probolinggo, Indonesia(2) \\ Pendidikan Agama Islam, Universitas Nurul Jadid, Paiton, Probolinggo, Indonesia(3) \\ Pendidikan Islam Anak Usia Dini, Universitas Nurul Jadid, Paiton, Probolinggo, Indonesia(4) \\ DOI: $\underline{10.31004 / \text { obsesi.v6i4.2123 }}$
}

\begin{abstract}
Having a strategy to increase the institution's competitiveness provides positive energy for an institution to develop the institution. This study analyzes and examines strategies to increase competitiveness through public demand intermediaries at RA Masyitoh III Sumberanyar Paiton Probolinggo. This research uses a qualitative approach. Technical analysis of the data through interviews, observation, and documentation is then carried out reduction which is processed on the display of the last data drawing conclusions. Research shows results; the strategy of increasing the competitiveness of public demand in RA Masyitoh III is carried out by creating school branding, public engagement, and continuous improvement through evaluation of the implementation of school branding and public engagement that has been running. From the study results, the public demand strategy carried out by RA Masyithoh III became a breakthrough for institutions at the level in the Paiton region that do not have a marketing strategy. The implications for the institution are that the institution is increasingly recognized by the broader community with increasingly highlighted characteristics. The implications for teachers are that teachers will further increase their competence in their respective fields to keep up with the institution's development.
\end{abstract}

Keywords: strategic institutions; increasing competitiveness; public demand

\begin{abstract}
Abstrak
Memiliki strategi dalam meningkatkan daya saing lembaga memberikan energi positif terhadap sebuah lembaga dalam mengembangkan lembaga tersebut. Penelitian ini memiliki tujuan dalam menganalisis dan mengkaji tentang strategi peningkatan daya saing melalui perantara public demand di RA Masyitoh III Sumberanyar Paiton Probolinggo. Penelitian ini menggunakan pendekatan kulitatif. Teknis analisis data melalui interview, observasi dan dokumentasi kemudian dilakukan reduksi yang diolah pada display data terakhir penarikan kesimpulan. Penelitian menunjukkan perolehan hasil; strategi peningkatan daya saing berasis public demand di RA Masyitoh III dilakukan dengan cara membuat school branding, pelibatan publik, dan continuous improvement melalui evaluasi pelaksanaan school branding dan pelibatan publik yang telah berjalan. Dari hasil penelitian tersebut, strategi public demand yang dilakukan RA Masyithoh III menjadi terobosan baru bagi lembaga setingkat di wilayah Paiton yang tidak memiliki strategi marketing. Implikasi yang diperoleh bagi lembaga, lembaga semakin dikenal oleh masyarakat luas dengan ciri khas yang semakin ditonjolkan, implikasi bagi guru, guru akan semakin meningkatkan kompetensinya dalam bidangnya masing-masing demi mengikuti perkembangan lembaga.
\end{abstract}

Kata Kunci : strategi lembaga; peningkatan daya saing; public demand

Copyright (c) 2022 Zamroni, et al.

$\triangle$ Corresponding author:

Email Address : iceisa.iainsmd18@gmail.com (Samarinda, Indonesia)

Received 22 October 2021, Accepted 6 January 2022, Published 4 February 2022

2886 | Jurnal Obsesi : Jurnal Pendidikan Anak Usia Dini, 6(4), 2022 


\section{INTRODUCTION}

In an era that is growing, the intensity of educational development is also getting higher. The world of education is increasing with many new educational seeds that can compete with the existing education (Widat \& Efanadari, 2021). Several fields of work in academic institutions are intended to build and maintain the image of educational institutions in the eyes of users of educational services themselves. Farizal (2021) thinks that the institution's vision is essential and must be maintained in the public's eyes, both internal and external. Public relations management is very closely related to an "image," which is the formation of a reputation that Islamic educational institutions will recognize.

In line with the opinion above, Amalia (2020) explains that public trust in educational institutions, including early childhood education, can be built with public relations strategies, including getting used to good communication with the community. Therefore, PAUD institutions as educational service organizations need to develop a good communication image to all levels of society because good communication will impact public trust in aspects of the quality of education in schools. (El Iq Bali et al., 2020).

Competitiveness is increasingly seen with the competition of institutions proclaiming the excellence of schools. Of course, this makes the institutions that are less well developed both in terms of quality and quantity in these institutions worried. When an institution does not have good competitiveness, it causes the institution to be forced to close because the number of applicants decreases drastically to enter the institution. This problem, which is currently covering the RA Masyitoh III Sumberanyar Paiton institution, a raudlatul athfal institution under the auspices of the Nurul Yaqin Foundation, is being visited with anxiety due to the number of neighboring institutions that are superior and have up-to-date programs. Rise in increasing competitiveness against other institutions.

Based on the existing problems, RA Masyitoh III is now trying to improve the institution's competitiveness to improve the quality and image of the institution in the community's eyes and have an attractiveness for the community. This increase in competitiveness is carried out by creating a unique school program packaged into exciting information so that the public knows and is interested in sending their children to RA Masyithoh III. In line with this, competitiveness is needed for educational institutions; as stated by several previous researchers, including Sa'dullah \& Supriyatno (2021) noted that competitiveness needs to be improved considering the rapid dynamics of increasing educational institutions in Indonesia cannot be avoided, significantly to minimize the rapid development of institutions. Then Trisnantari (2018) said that this empowerment was carried out to help schools improve the quality of education and school competitiveness to make them more attractive to the community.

Next, Hadiansyah et al. (2015) said that empowering the community helps understand the importance of education for children, especially understanding the guardians of students because the trust of guardians of students can improve the development of the institution's future. Wahjosumidjo (2011) opinion said that the managerial competence of the head of early childhood education is related to planning, organizing, leading, and controlling institutions so that goals are achieved. Then the competence of the educators, which includes pedagogic, professional, social, and personality, also supports the quality of the institution's competitiveness (Ulfah, 2015).

In the case faced by RA Masyitoh III in terms of making a strategy to increase the competitiveness of the stakeholders and the management of RA Masyitoh III has coordinated with the Foundation, namely by choosing to implement Intercultural Communication: Strategy to Increase Competitiveness of Institutions based on Public Demand. Public demand is deemed capable of providing solutions to the institution's phenomena; this is based on the premia reset carried out by experts. Aneta (2012) said that a strategy involving public involvement is also needed in achieving shared goals. Also found by Margareta et al. (2018), 
public demand strategy can be used as a marketing strategy that can bring a breakthrough in institutions to achieve a goal.

Education is often interpreted as a process that can change a person to be better, more independent, and understand more responsibilities. Because the educational process will produce feedback regarding the quality of life in the future (Watini, 2019). Early childhood education is an essential process for its implementation to form the basis of human character. Education aimed at early childhood is formal education for children aged 0-6 years before entering elementary school (Wahid et al., 2021).

Early childhood education includes an effort to encourage guidance, care, and stimulation, leading to the child's abilities and skills (Amir \& Saleha, 2021). Education for early childhood is carried out through playing while learning through games so that children will get enjoyable learning, especially during the golden age around the age of 0-6 years. (Syam \& Damayanti, 2020). Providing educational stimulation to early childhood does not mean spending expensive fees or involvement of certain institutions because education can start from the home environment or closest family (Ahmad \& Masykuroh, 2021).

Educational needs are included in the conditions that are important in this life. In ensuring the survival of human beings, both individually, nationally, and socially, education is one of the most basic needs (Setyowahyudi, 2020). Education has a significant role in improving human resource quality, especially in preparing independent, creative, innovative, and professional students (El Iq Bali et al., 2020).

In the education system in Indonesia, early childhood education can be divided into formal and informal education. Informal and/non-formal education for early childhood, such as Learning Groups (KB) and Child Care Parks (TPA), which do not emphasize the existence of a diploma and do not have a centralized curriculum. While formal education for early childhood, such as Raudhatul Athfal (RA) and Kindergarten (TK), which have a centralized curriculum as regulated in Law no. 20 of 2003 concerning the National Education System and emphasizes the existence of a diploma (Haerullah \& Elihami, 2020). Formal educational institutions such as Raudhatul Athfal, who want progress and success for an extended level, must compete and practice sustainable marketing strategies because there are many traditional educational institutions under the auspices of various government-owned institutions or certain foundations. The number of students affects the institution's financial welfare and teaching and learning activities to produce quality output (Maisah et al., 2020). The utilization of public demand in maintaining the institution's quality is very influential on the institution's future.

The descriptions from several researchers explain the importance of using public demand to increase the competitiveness of the Raudhatul Athfal institution and maintain the institution's sustainability so that it continues to advance and exist in the future. Based on this, the researchers are interested in reviewing the strategy to increase the competitiveness of institutions through the internalization of culture based on public demand.

\section{METHODOLOGY}

This study uses qualitative research methods to describe the problem and analyze the issues. The institution chosen in this study was completed at an institution under the auspices of the Nurul Yaqin Foundation. This early childhood education institution is more familiar with RA Masyitoh III. The location is in Sumberanyar village, Paiton sub-district, Probolinggo district.

Researchers collect data through several stages: observation activities, direct observations at the research location, namely RA Masyitoh III. Then conducted an interview session with the principal, all teachers, employees, and guardians of RA Masyitoh III students. Furthermore, observations were made at several meetings to observe public demand activities carried out by the institution directly. The last is the analysis of documents that can corroborate the research results. 
All data collected is then data reduction is carried out, processed on the data display, and drawn conclusions. The researcher can analyze and conclude the research conducted through the stages carried out.

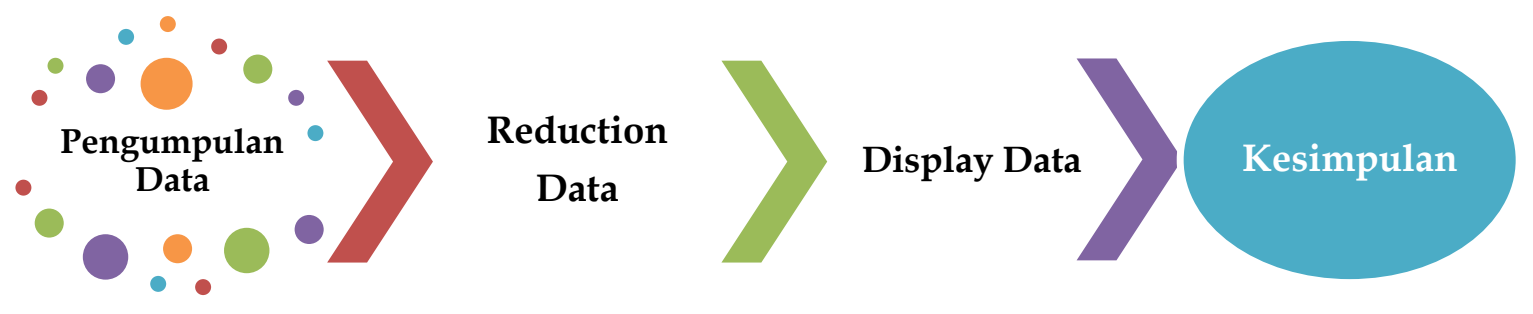

Figure 1. Data Collection Process

\section{RESULTS AND DISCUSSION}

The results showed that; Intercultural Communication: Strategy to Increase Competitiveness of Public Demand-based Institutions carried out at RA Masyitoh III Nurul Yaqin Foundation Sumberanyar Paiton Probolinggo with the following programs;

\section{School Branding}

Planning for new program activities is essential for the smoothness and success of the program. Program planning can help stakeholders sort out the points needed to implement new ideas that will be implemented both in institutions and organizations. In the initial planning, RA Masyitoh III carried out school branding in introducing the institution to the general public.

The principal said that school branding was carried out to make a good impression on the public about the condition of the school. Introducing the school by completing all the necessary facilities, both from human resources and infrastructure, to support teaching and learning activities at RA Masyitoh III.

School branding is an effort to provide a brand or brand to schools as a form of service with promises and values (positioning) that have differences or characteristics with other schools (differentiation) to influence other people (strategy) to make choices in certain institutions (Fidhiyanti et al., 2019).

Class A's homeroom teacher confirmed from the principal's statement that this school branding was a new effort that the school brought up to make the RA Masyitoh III institution distinctive from other institutions. The principal and the teacher have agreed to make their uniqueness, which is most highlighted, namely the hafidzul Qur'an through the Wafa method, which is broadcast with social media involvement.

Branding is a mechanism to highlight the hallmark of the school and a place for school promotion (Syafitri \& Costaner, 2019). Highlighting branding while still understanding consumers can be seen from their lifestyles, such as consumer demand for publicity, gender tastes, age development, and consumer response to new products. This also concerns race, ethnicity, religion, location, and others (Rohanah \& Agustina, 2018)

The school branding owned by RA Masyitoh III is tahfidzul Qur'an through the Wafa method; the school environment is already aware of the existence of these little hafidzahs by proving that they have participated in various competitions so that the layers of society around RA Masyitoh III already know when they hear the chanting of the holy verses of al-Qur'an. The Qur'an uses the Wafa method, namely students from RA Masyitoh III. 


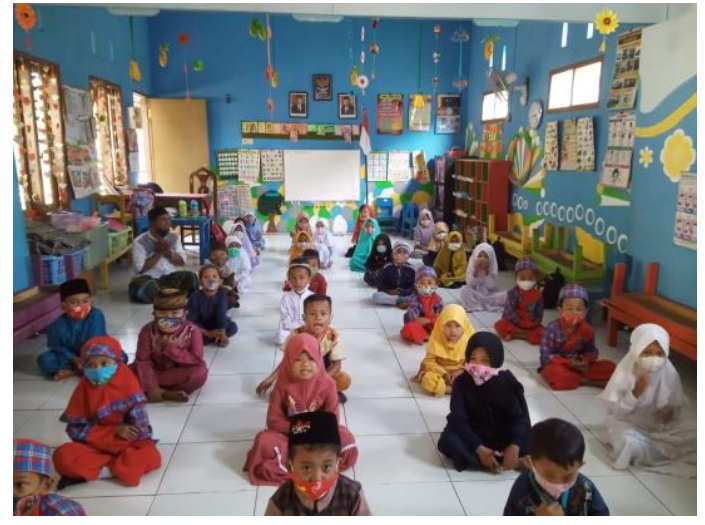

Figure 2 Tahfidzul Quran with the Wafa method

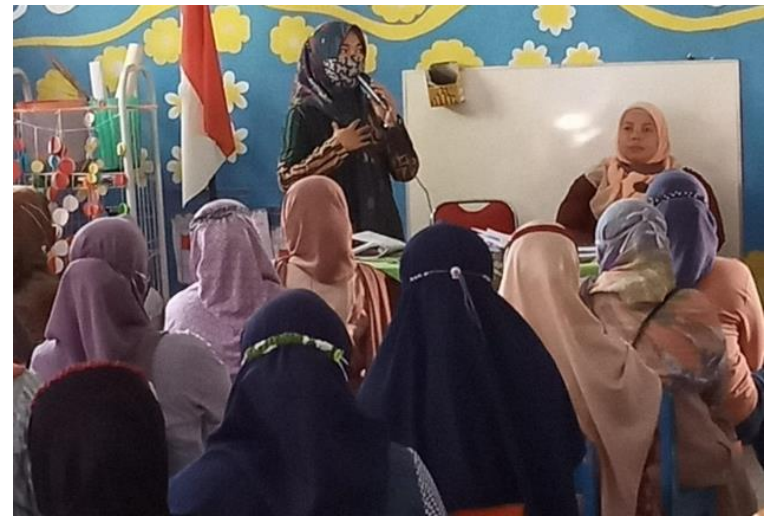

Figure 3 Socialization of the RA Masyithoh III program to Learning Group institutions or Child Care Parks in the surrounding environment

In Figure 2, it can be seen that the students of RA Masyithoh III are repeating the Quran reading as one of the only programs of tahfidzul Quran with the Wafa method. Of course, the school branding that has been attached to RA Masyitoh III is not just a name but is also proven by real applications in schools. School branding is a way in which students can apply some form of cultivation to become a hafidz and a hafidzah who will be the successor in the future.

By having branding, an institution has a characteristic that is easily recognized by the general public so that schools have a plus value from other schools that do not highlight their branding.

\section{Public Engagement}

The strategy to increase the competitiveness of institutions carried out with the public demand program is part of the new strategy at RA Masyitoh III in conducting broad school promotions to the community, where promotion is the most potent means for an institution to attract and maintain stability of public trust in the institution by public involvement demand. Promotion in the scope of education, namely by offering educational services to consumers (Alma \& Hurriyati, 2015)

The principal said that promotions need to be carried out to introduce existing programs in our school, exceptional programs, or new programs that are not yet known to the public so that the wider community can realize them. Therefore schools involve public relations in developing these programs. The implementation of program introduction by applying programs that have been planned and planned must be energetic and attractive to get public attention (Amir \& Saleha, 2021).

It was also continued by the homeroom teacher of group A who said that promotion could be done through mass communication, group communication, and interpersonal communication. In today's modern era, the hype is felt by some institutions to be more effective through social media because the reach of social media is extensive, reaching almost all regions of the world. However, several institutions still rely on direct promotion or what we usually know as the door to door or face to face.

The following is the implementation of the strategy to increase the competitiveness of institutions in implementing the public demand of RA Masyitoh III:

\section{Community Leader Approach}

By approaching local community leaders, the institution has more opportunities to maximize public trust. It can also contribute to the institution in digging information on existing figures regarding the interests and needs of the community in education. 
Hidayati as a mentor teacher, conveyed that an approach to community leaders it made it easier for institutions to make plans and determine targets for public demand by knowing which requests were dominant and less dominant in the institution.

Arini Setyowati as the homeroom teacher for group B, also stated that competition among institutions is getting tighter in promoting school programs. The diverse desires of the surrounding community have made institutional administrators compete to improve the quality of education in various ways. Of course, this must also be shown to the general public so that the wider community is more interested in sending their children to this institution with the contribution of community leaders.

By involving community leaders, the target of public demand is increasingly visible and can provide excellent opportunities for institutions to approach all levels of society and meet general needs.

\section{Targets and Strategies Promotion of public demand}

Promotional targets need to be carried out in determining which areas are explicitly required for the strategy to increase competitiveness based on public demand.

Hidayati conveyed that the promotion target carried out by RA Masyitoh III was to approach schools for the AUD level in the surrounding environment. This is done by making visits or through friendly competitions. This activity carried out promotional activities regarding the RA Masyitoh III institution.

Furthermore, Fuad Akbar said that the promotion target in increasing competitiveness was also carried out by approaching the alumni of RA Masyitoh III. Where alumni already know the quality that exists in this institution and can broadcast to the general public about the activities in the institution.

The promotion target in increasing the competitiveness of public demand-based institutions is carried out at institutions under the Raudlatul Athfal level, namely PAUD (Early Childhood Education) institutions in the RA Masyitoh III institution environment.

The promotion target also emphasizes the public demand-based promotion strategy carried out by the RA Masyitoh III institution, based on some of the data presented and the promotion strategy for increasing competitiveness based on public demand carried out at RA Masyitoh III;

\section{Door To Door (OF Line)}

Door to door means by promoting schools by conducting outreach to schools under RA Masyitoh III in the school environment within the scope of one village or sub-district by communicating well. Communication will be established well if the ideas discussed are shared between the communicator and the communicant (Morissan, 2014).

As shown in Figure 3, RA Masyithoh conducts outreach to institutions below RA, such as study groups or Child Care Parks in the surrounding area. The socialization was carried out to promote RA Masyithoh III's excellence and introduce the institution to the surrounding community. Fuad Akbar as the public relations officer for the Nurul Yaqin Foundation, emphasized that in the door to door strategy, the school also utilizes the promotion team that the institution has selected in providing information to the public, the door to door promotion team is chosen from among teachers and alumni who are assigned directly to schools that have become the target is to describe some of the excellent programs and qualities that exist in the RA Masyitoh III school.

Door-to-door efforts are also carried out by establishing a partnership with junior high schools. Many activities are carried out in establishing this partnership, namely by conducting friendly visits, competitions between schools, outreach to schools, and more collaborative relationships with the community and other institutions. 


\section{Public Promotion Through Media}

The use of media in conducting promotions effectively attracts consumer enthusiasts. RA Masyitoh III uses two media elements in promoting competitiveness, namely; 1) Manual Media: The school principal revealed manual media in brochures, banners, and banners. RA Masyitoh III banners and banners are print media installed in strategic places on the edge of the highway, namely on the side of the road. The installation of banners and banners is carried out once a year in the new school year. Print media promotion is relatively easy and provides teachers with information relief. 2) Electronic Media: In this increasingly sophisticated era, RA Masyitoh III also utilizes electronic sophistication to promote school programs to increase competitiveness based on public demand.

Fuad Akbar said that the electronic media used were Whatsapp, Facebook, Telegram, and Instagram by marketing content in posts, images, and videos. The content that is informed through social media is related to the special programs in the school. All institutional stakeholders carry promotion through social media, starting from school principals, committees, foundations for teachers and employees.

Focusing on one social media is highly recommended, but if you can master several social media well, promotions can run smoothly. In making promotions using social media, it is advisable to display uniqueness so that the target is interested in seeing or reading. Advertisements can use images, videos, or light content to attract prey.

\section{Join the Competition}

Competitions are very popular with various groups in testing their talents. Especially for parents who want to show their children's talents. This becomes a strategy that can attract the public to be more curious about the institution.

The school principal emphasized that in RA Masyitoh III, he often included his students in competitions starting at the sub-district, district, and provincial levels. Thus the results of the hard work done by the teachers can be displayed to the public; this is at the same time promoting the institution of RA Masyitoh III.

Hidayati also conveyed that through the various championships won by RA Masyitoh III, the public's trust in our institution has also increased. In addition to participating in competitions from outside the institution itself, it often holds rounds to stimulate students' enthusiasm in developing their talents.

\section{Continuous Improvement}

To see the program's success, the next step is to improve the program by evaluating the implementation of Intercultural Communication: Strategy to Increase Competitiveness of Public Demand-based Institutions at RA Masyitoh III. This evaluation can be a stage of improvement in making decisions that use a set of measurement results and refer to the goals that have been set.

The principal conveyed that evaluation activities on strategies to increase the competitiveness of public demand-based institutions at RA Masyitoh III were carried out to improve competitiveness strategies that were more targeted and could meet the desired targets.

Evaluation measures and improves the implemented activities, such as matching the results of actions. The purpose of the assessment is so that the plans that have been arranged can achieve the goals set and be implemented. The evaluation results are intended for replanning and serve as the last administration and management (Wibowo, 2021).

Fuad Akbar also emphasized that to improve and revamp our promotional activities, we held a coordination meeting attended by all the teams involved, including school principals, committees, teacher boards, employees, parents, alumni, and sympathizers who could help provide input for improvement. Competitiveness strategy in the next step. 
After implementation, continuous improvement is carried out. The next step is to ensure the affordability of the physical and structural elements of the planned program. The next step is the program evaluation stage, making the necessary assessments and improvements to maximize results.

Evaluation is critical in developing the quality of education. Because evaluation can encourage students to be more active in continuous learning, encourage teachers to improve the quality of the learning process further and enable schools to strengthen additional facilities and the quality of student learning (Firdausiah, 2021). For this reason, it is necessary to have qualified human resources to fix and improve the management of early childhood education, specifically related to early childhood education learning, which includes planning, organizing, implementing, and assessing (Ita, 2018).

Evaluation of the implementation of public relations based on electronic word of mouth in building public trust in RA Masyitoh III has been set to conduct an assessment twice a year. First, an evaluation was carried out when the curriculum was formed; then, an evaluation was carried out in the first semester to determine the success of the public demandbased strategy program.

Evaluation is a process that provides an overview of what is happening in a program and ensures the affordability of the physical and structural elements of the planned schedule. Through evaluations carried out in evaluating the system, it can provide direction and further improvements to optimize programs that are already running. This allows institutions that are more advanced and can prioritize the needs of students to guide, develop and direct more optimal learning goals.

From the public demand strategy implemented by RA Masyithoh III, the result is that the public's attractiveness to send their children to RA Masyithoh III has increased. Specifically, Figure 4 is a picture of the flow of implementing the public demand strategy and the results obtained.

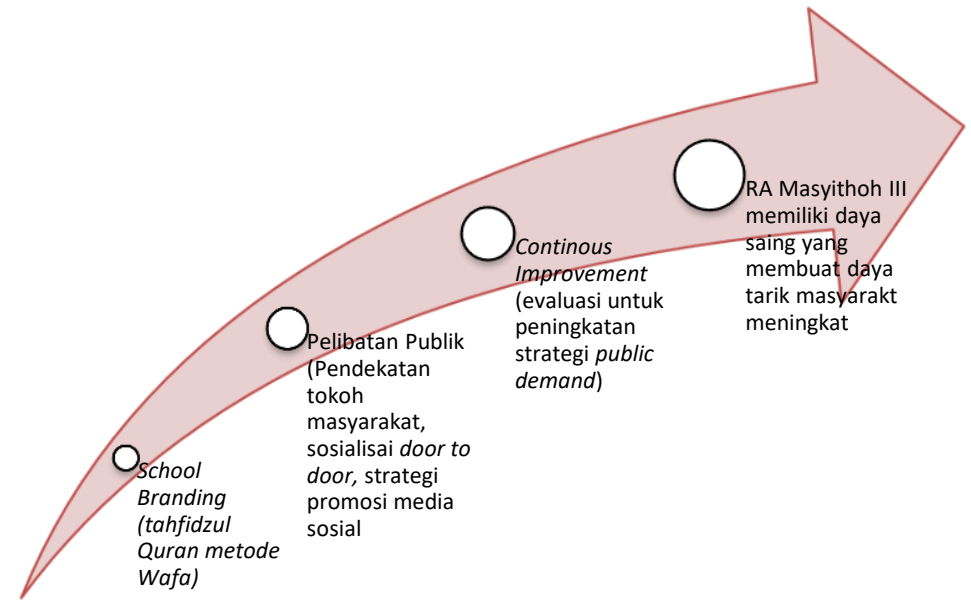

Figure 3 Flow of Public Demand Strategy Implementation and the results obtained by RA Masyithoh III

\section{CONCLUSION}

The public demand strategy at RA Masyithoh III, Sumberanyar, Paiton, Probolinggo was carried out to increase the institution's competitiveness by implementing school branding, public involvement, and continuous improvement. Through this strategy, RA Masyithoh III can gain more recognition from the community so that it is effective in attracting people to use the services offered by RA Masyithoh III. However, this strategy cannot be generalized to all institutions because each institution has a different culture and climate. This opens up opportunities for further researchers to study the same thing but in a more comprehensive manner, of course, by adjusting to the institution's conditions. 


\section{ACKNOWLEDGMENT}

The author would like to thank all those who have provided support and support in completing this research, either directly or indirectly. Special thanks go to the Chancellor of the Sultan Aji Muhammad Idris State Islamic University, Samarinda and the Chancellor of the University of Nurul Jadid Paiton Probolinggo, the Dean of the University of Nurul Jadid Paiton Probolinggo, and the Head of the PIAUD Study Program at Nurul Jadid University Paiton Probolinggo and to the RA Masyitoh III Sumberanyar Paiton Probolinggo institution which has provided motivation and support so that the writing of this article can be completed on the specified deadline.

\section{REFERENCES}

Ahmad, Z., \& Masykuroh. (2021). Strategi Kepala Sekolah dalam Menerapkan Program Perilaku Hidup Bersih dan Sehat (PHBS) pada Anak Usia Dini. Jurnal Pendidikan Anak, 10(1), 59-68. https:// doi.org/10.36722/jaudhi.v3i1.588

Alma, B., \& Hurriyati, R. (2015). Manajemen Corporate \& Strategi Pemasaran Jasa Pendidikan Fokus pada Mutu dan Layanan Prima. In Bandung: Alfabeta (pp. 11-59).

Amalia, V. (2020). Strategi Komunikasi Humas Dalam Meningkatkan Public Trust Di Perguruan Tinggi(Studi Kasus di Universitas Nurul Jadid, Paiton, Probolinggo). ALTANZIM: Jurnal Manajemen Pendidikan Islam, 4(1), 13-23. https://doi.org/10.33650/al-tanzim.v4i1.812

Amir, \& Saleha, L. (2021). Pengelolaan APE Berbahan Limbah untuk Meningkatkan Kecerdasan Kognitif Anak. Jurnal Pendidikan Anak Usia Dini, 5(2), 1382-1395. https:// doi.org/10.31004/obsesi.v5i2.763

Aneta, Y. (2012). Strategi Publik Dalam Dinamika Permintaan Dan Penawaran. Jurnal Pelangi Ilmu, 5(1), 1-12.

El Iq Bali, M. M., Firdaus, S., Wijaya, M., Al Mursyidi, R. A., Haqiki, M. W., \& Abidin, Z. (2020). Learning management; identifying learning styles of language learners in madrasah. Proceedings of the International Conference on Industrial Engineering and Operations Management, August, 3783-3790.

Farizal, A. (2021). Image Building Through Public Relation Management: A Case Study On Private Primary School In Bantul. International Journal of Educational Management and Innovation, 2(1), 1-30. https:// doi.org/10.12928/ijemi.v2i1.2248

Fidhiyanti, E. F., Katni, \& Abidin, N. (2019). Penanaman Karakter Islami Berbasis School Branding di SMPN 3 Slahung Ponorogo. Al-Idarah: Jurnal Kependidikan Islam, 8(2), 324-337. https://doi.org/10.24042/alidarah.v8i2.3423

Firdausiah, F. (2021). Implementation of Role-Playing Games in Overcoming Introverted Children. AL-ISHLAH: Jurnal Pendidikan, 13(2), 1394-1402. https:// doi.org/10.35445/alishlah.v13i2.629

Hadiansyah, A., Fidesrinur, F., \& Firmiana, M. E. (2015). Strategi Pemberdayaan Masyarakat dalam Pendirian Lembaga PAUD. Jurnal Al-Azhar Indonesia Seri Humaniora, 3(1), 5568. https://doi.org/10.36722/sh.v3i1.197

Haerullah, \& Elihami. (2020). Dimensi Perkembangan Pendidikan Formal dan Non Formal. Jurnal Edukasi Nonformal, 1(1), 199-207.

Ita, E. (2018). Manajemen Pembelajaran Pendidikan Anak Usia Dini Di Tk Rutosoro Kecamatan Golewa Kabupaten Ngada Flores Nusa Tenggara Timur. Jurnal Dimensi Pendidikan Dan Pembelajaran, 6(1), 45-52.

Maisah, Mahdayeni, Maryam, \& Alhaddad, M. R. (2020). Penerapan 7P Sebagai Strategi Pemasaran Pendidikan Tinggi. Jurnal Ekonomi Manajemen Sistem Informasi, 1(4), 325333. https://doi.org/10.31933/jemsi.v1i4.116

Margareta, R. T. E., Ismanto, B., \& Sulasmono, B. S. (2018). Strategi Pemasaran Sekolah Dalam Peningkatan Minat Peserta Didik Berdasarkan Delta Model. Kelola: Jurnal Manajemen Pendidikan, 5(1), 1-14. https://doi.org/10.24246/i.jk.2018.v5.i1.p1-14 
Morissan. (2014). Teori Komunikasi Individu Hingga Massa. In Jakarta: Kencana Prenadamedia Group.

Rohanah, A., \& Agustina, S. (2018). Promotion Based on Emotional Branding At Kineruku Library. Edulib, 8(2), 135-155. https://doi.org/10.17509/edulib.v8i2.13552

Sa'dullah, A., \& Supriyatno, T. (2021). Peningkatan Mutu Sumber Daya Manusia Lembaga Pendidikan Islam Berbasis Sustainable Development Goals Di Yayasan Pendidikan Anak Saleh Kota Malang. Jurnal Manajemen Pendidikan Islam Is Licensed under The, 5(1), 182-199. https://doi.org/10.32478/evaluasi.v5i1.634

Setyowahyudi, R. (2020). Pemikiran Ki Hajar Dewantara dan Maria Montessori tentang Pendidikan Anak Usia Dini. PAUDIA : Jurnal Penelitian Dalam Bidang Pendidikan Anak Usia Dini, 9(1), 17-35. https:/ / doi.org/10.26877/paudia.v9i1.5610

Syafitri, W., \& Costaner, L. (2019). Pelatihan Branding Sekolah Pada Sosial Media di SMP IT Madani. Dinamisia: Jurnal Pengabdian Kepada Masyarakat, 3(1), 158-166. https://doi.org/10.31849/dinamisia.v3i1.2804

Syam, A. F., \& Damayanti, E. (2020). Capaian Perkembangan Bahasa Dan Stimulasinya Pada Anak Usia 4 Tahun. PAUDIA : Jurnal Penelitian Dalam Bidang Pendidikan Anak Usia Dini, 9(2), 71-88. https:// doi.org/10.26877/paudia.v9i2.6235

Trisnantari, H. E. (2018). Pemberdayaan Guru Pendidikan Anak Usia Dini (Paud) Di Kecamatan Kedungwaru Dalam Membentuk Karakter Anak Yang Kreatif. J-ADIMAS (Jurnal Pengabdian Kepada Masyarakat), 2(1), 1-9.

Ulfah, F. (2015). Manajemen PAUD: Pengembangan Jejaring Kemitraan Belajar. In Yogyakarta: Pustaka Pelajar (p. 207).

Wahid, A. H., Rozi, F., Baharun, H., Hidayati, W., \& Bon, A. T. (2021). Information Technology in the Development of Language Aspects of Early Childhood.

Wahjosumidjo. (2011). Kepemimpinan Kepala Sekolah: Tinjauan Teoritik dan Permasalahannya. In Jakarta:Rajawali Press (p. 96).

Watini, S. (2019). Implementasi Model Pembelajaran Sentra pada TK Labschool STAI Bani Saleh Bekasi. Jurnal Obsesi: Jurnal Pendidikan Anak Usia Dini, 4(1), 110-123. https://doi.org/10.31004/obsesi.v4i1.190

Wibowo, A. (2021). Kepemimpinan Perempuan dalam Menciptakan Sekolah Ramah Anak. Quality, 9(1), 87-102. https://doi.org/10.21043/quality.v9i1.10109

Widat, F., \& Efanadari, E. (2021). Implementasi Model Pembelajaran Picture and Picture dalam Meningkatkan Hasil Belajar Anak Usia Dini. Murobbi; Jurnal Ilmu Pendidikan, 5(1), 128-142. https://doi.org/10.21107/pgpaudtrunojoyo.v8i2.10691 